\title{
Behavioural and emotional symptoms among schoolchildren: a comparison between Jordanians and Syrian refugees
}

Othman Beni Yonis, ${ }^{1}$ Yousef Khader, ${ }^{1}$ Abdel-Hameed Al-Mistarehi, ${ }^{1}$ Sara Abu Khudair ${ }^{2}$ and Mourad Dawoud ${ }^{3}$

${ }^{1}$ Department of Public Health and Family Medicine, Faculty of Medicine, Jordan University of Science and Technology, Irbid, Jordan (Correspondence to: Othamn Yonis: oabaniyonis@just.edu.jo). ${ }^{2}$ Department of Public Health and Epidemiology, Faculty of Medicine, University of Debrecen, Debrecen, Hungary. ${ }^{3}$ Jordan University of Science and Technology, Irbid, Jordan.

\begin{abstract}
Background: There is a high prevalence of mental illnesses, including depression, anxiety, nicotine dependence, and sleep disorders among Jordanian adolescents and schoolchildren. There are many young Syrian refugees in Jordan, who have an increased risk of physical and psychological illnesses.

Aims: To assess the behavioural and emotional symptoms among Syrian schoolchildren refugees in Jordan and their Jordanian counterparts.

Methods: A cross-sectional, descriptive study was conducted from October to December 2018 on Syrian and Jordanian schoolchildren, aged 12-17 years, attending the same schools in 4 cities with the highest density of Syrian refugees. A self-reported questionnaire was used to collect information about sociodemographic characteristics. The Strengths and Difficulties Questionnaire was used to measure behavioural and emotional symptoms.

Results: This study included 1877 Jordanian schoolchildren and 1768 Syrian schoolchildren refugees. The Syrian children's parents were significantly less educated and had significantly lower incomes and larger families than Jordanian parents had. The total difficulties and peer relationship problems were abnormally high in more than half of children. Compared to Jordanians, Syrian schoolchildren had more total difficulties (58.2\% vs 52.5\%), and peer relationship (55.5 vs 53.6\%), conduct (47.6\% vs $44.8 \%$ ), and emotional problems (32.0\% vs $30.8 \%$ ), but they had fewer hyperactivity/inattention problems (35.5\% vs $36.9 \%$ ), and prosocial behaviour problems (42.5\% vs 43.0\%). In binary logistic regression, Syrian were more likely than Jordanian schoolchildren to experience overall difficulties and emotional symptoms.

Conclusion: There were significant but unspoken behavioural and emotional symptoms and mental health needs among Syrian and Jordanian schoolchildren. They are all in need of urgent psychosocial support.

Keywords: schoolchildren; Syrian refugees; Jordan; behavioural symptoms; emotional symptoms

Citation: Beni Yonis O; Khader Y; Al-Mistarehi AH; Abu Khudair S; Dawoud M. Behavioural and emotional symptoms among schoolchildren: a comparison between Jordanians and Syrian refugees. East Mediterr Health J. 2021;27(12):1162-1172. https://doi.org/10.26719/emhj.21.072

Received: 20/02/21; accepted: 10/10/21

Copyright (C) World Health Organization (WHO) 2021. Open Access. Some rights reserved. This work is available under the CC BY-NC-SA 3.0 IGO license (https://creativecommons.org/licenses/by-nc-sa/3.o/igo)
\end{abstract}

\section{Introduction}

Globally, > 790 million people suffer from mental health disorders, which are one of the leading causes of disability worldwide $(1,2)$. Mental health refers to a broad array of activities related to the mental wellbeing component of health that is defined by the World Health Organization (WHO) as "a state of complete physical, mental and social wellbeing, and not merely the absence of disease" (3). Previous studies have indicated that most adult mental disorders have their onset in youth (age 14-24 years) $(4,5)$. Jordan is a small low- to middle-income country in the Eastern Mediterranean Region bordering the Syrian Arab Republic, West Bank, Iraq and Saudi Arabia. The mental health system in Jordan needs strengthening (6). It was chosen as the first country to implement the WHO Mental Health Action Program (mhGAP) from among 6 countries worldwide (6). Recent national Jordanian studies found a high prevalence of mental illnesses, including depression, anxiety, nicotine dependence, and sleep disorders among Jordanian adolescents and schoolchildren (7-14).
According to the United Nations High Commissioner for Refugees (UNHCR), the Syrian Civil War has led to the biggest humanitarian and refugee crisis of our time (15). As of June 2021, the UN estimated that > 5.6 million Syrian refugees were registered outside the Syrian Arab Republic, making it the world's second-largest refugee population (16). About half of these refugees were aged < 18 years, and around 40\% were under 12 years (17). Jordan, a neighbouring country of Syria, has hosted hundreds of thousands of refugees from neighbouring countries since 1948. According to the national census, Jordan's population was 10.309 million in 2018 (18), with approximately 660836 Syrian refugees: $3.8 \%$ older people, $45.2 \%$ adults and $51.0 \%$ children (19). Although the country is politically stable, there are limited economic resources to support the rapid population growth caused by the large influx of refugees. The presence of Syrian refugees has affected Jordan's economy, society, security and quality of life, and has drained the Government's resources (20). An estimate of the direct cost to the Jordanian Government to address 
Syrian refugees' needs since the Syrian crisis in 2011 until 2016 was about 4.2 billion US dollars (21).

Refugees, in particular children, have an increased risk of physical and psychological illnesses $(22,23)$. Previous studies of refugee children have reported profound adverse consequences of war-related trauma on their mental and psychosocial health, including behaviour problems, mood and anxiety disorders, posttraumatic stress disorder (PTSD), adjustment difficulties, panic attacks, self-withdrawal, aggressive behaviour, insecurity, and violence (24-28). Furthermore, war crisis and displacement have had a major impact on the academic, economic and health aspects of adolescents (29). In Jordan, a study of Syrian refugee adolescents in the Alza'atari Refugee Camp reported that adolescents struggle with grief, fear, sadness and violent behaviour (30). In another study, Syrian female adolescents showed more prosocial behaviour than boys but more emotional and conduct difficulties (31). Data on behavioural and emotional symptoms among Syrian schoolchildren refugees are scarce. Thus, this study aimed to assess schoolchildren's behavioural and emotional symptoms and compare Syrian refugees with Jordanians attending the same schools. In light of the impacts of war on Syrian refugees, we hypothesize that Syrian schoolchildren refugees would have more behavioural and emotional symptoms than their Jordanian peers.

\section{Methods}

\section{Population, sampling and ethical approval}

The study was conducted on a sample of Syrian and Jordanian children, aged 12-17 years, who attended primary and secondary schools in Jordan from October to December 2018. We selected 4 large cities in Jordan (Mafraq, Sahab, Ramtha and Zarqa) because they have hosted most Syrian refugees from the 2011 Syrian civil war. Eight schools were selected randomly from each city; therefore, 32 schools were involved, 16 for boys and 16 for girls, with 5576 registered students (2120 Syrian and 3156 Jordanian). All registered students were invited to participate in the survey. Written informed consent was obtained from the children and their legal guardians. The study was approved by the Institutional Review Board of Jordan University of Science and Technology Ethical Committee. Participants did not receive any compensation or reward for their participation.

\section{Sample size and power}

The sample size was calculated for Jordanian and Syrian schoolchildren separately. An estimate of the prevalence of behavioural and emotional problems in each group was assumed to be $50 \%$ to yield the maximum sample size. The sample size was calculated at a 2-sided alpha level of $5 \%$ and $80 \%$ power. The sample size needed to estimate the prevalence with a margin of error of $5 \%$ was 778 Jordanian and 778 Syrian adolescents. The targeted number of participants was increased to have sufficient power for subgroups defined by age and gender.

\section{Data collection}

The self-reported questionnaire was distributed among the participants and filled in by the children themselves in the absence of teachers and other school personnel. Firstly, it included questions about gender, income, parental education and marital status (living together, separated, divorced, or widowed), living area (apartment or house), and total family size. Participant date of birth and missed sociodemographic information that was not self-reported were taken from student's school files. Questions measuring behavioural and emotional problems were administered to participants using the Strengths and Difficulties Questionnaire (SDQ).

\section{SDQ}

The self-reported SDQ was used to measure behavioural and emotional symptoms among these children. The SDQ is a practical screening tool of the behavioural and emotional symptoms among children and adolescents, and it has been used for in-depth determination and understanding of adolescents' emotional and behavioural symptoms $(32,33)$. The SDQ has been translated to varii ous languages, including Arabic, and has valid and reliable crosscultural-psychometric properties (33-36). The self-reported SDQ consists of 25 items that measure 4 scales, covering four problem areas (emotional, conduct, hyperactivity/inattention, and peer problems) and a fifth scale of prosocial behaviour. The reliability (Cronbach's) was 0.82 for the overall difficulties, 0.75 for emotional symptoms, 0.72 for conduct problems, 0.69 for hyperactivity, 0.65 for prosocial behaviour, and 0.61 for peer problems (37). Also, it discriminates satisfactorily between low- and high-risk participants aged 11-16 years $(37,38)$. The Arabic version of SDQ had satisfactory areas under the curve ranging from 0.77 for the total difficulties scale to 0.89 for the conduct problems scale. Sensitivity and specificity were $72 \%$ and $55 \%$, respectively (36). Alyahri and Goodman tested the Arabic SDQ and reported that it accurately predicted psychiatric illness and was adequate for screening studies (39).

There are 5 items for each of the 5 scales mentioned above; each item can be marked "Not True", "Somewhat True", or "Certainly True", and each item can be scored with 0,1 or 2 . Thus, the scale score with 5 items ranges from 0 to 10 if all items are completed. The total difficulties score was generated by summing scores of the emotional symptoms, conduct problems, hyperactivity/inattention and peer problems scales but not the prosocial scale. The resulting score ranged from 0 to 40 , and the cutoff values for defining abnormal attributes were used as follows: total difficulties score considered abnormal 20-40, emotional problems score 7-10, conduct problems score 5-10, hyperactivity score 7-10, peer problems score 6-10, and prosocial score 0-4 (37). Table 1 summarizes the items and abnormal scores of self-report SDQ scales.

\section{Statistical analysis}

SPSS for Windows version 20 was used for data processing and analysis. Data were described using means 


\begin{tabular}{|c|c|c|}
\hline SDQ scales & Items $^{a}$ & Abnormal scores \\
\hline Prosocial Scale & $\begin{array}{l}\text { I try to be nice to other people. I care about their feelings } \\
\text { I usually share with others (food, games, pens, etc.) } \\
\text { I am helpful if someone is hurt, upset or feeling ill } \\
\text { I am kind to younger children } \\
\text { I often volunteer to help others (parents, teachers, children) }\end{array}$ & $0-4$ \\
\hline Emotional Symptoms Scale & $\begin{array}{l}\text { I get a lot of headaches, stomach-aches or sickness } \\
\text { I worry a lot } \\
\text { I am often unhappy, down-hearted or tearful } \\
\text { I am nervous in new situations. I easily lose confidence } \\
\text { I have many fears. I am easily scared }\end{array}$ & $7-10$ \\
\hline Conduct Problems Scale & $\begin{array}{l}\text { I get very angry and often lose my temper } \\
\text { I usually do as I am told } \\
\text { I fight a lot. I can make other people do what I want } \\
\text { I am often accused of lying or cheating } \\
\text { I take things that are not mine from home, school or elsewhere }\end{array}$ & $5-10$ \\
\hline Hyperactivity/Inattention Scale & $\begin{array}{l}\text { I am restless, I cannot stay still for long } \\
\text { I am constantly fidgeting or squirming } \\
\text { I am easily distracted, I find it difficult to concentrate } \\
\text { I think before I do things } \\
\text { I finish the work I'm doing. My attention is good }\end{array}$ & $7-10$ \\
\hline Peer Relationship Problems Scale & $\begin{array}{l}\text { I am usually on my own. I generally play alone or keep to myself } \\
\text { I have one good friend or more } \\
\text { Other people my age generally like me } \\
\text { Other children or young people pick on me or bully me } \\
\text { I get on better with adults than with people my own age }\end{array}$ & $6-10$ \\
\hline Total Difficulties Scale & $\begin{array}{l}\text { Summing scores of the scales: Emotional symptoms, Conduct problems, } \\
\text { Hyperactivity/inattention, and Peer problems }\end{array}$ & $20-40$ \\
\hline
\end{tabular}

${ }^{a}$ For all items except the 5 printed above in bold, the item is scored o for "Not True", 1 for "Somewhat True", and 2 for "Certainly True". For the 5 items printed in bold, the score is reversed as 2 for "Not True", 1 for "Somewhat True" and o for "Certainly True". $S D Q=$ Strengths and Difficulties Questionnaire

(standard deviation, SD) for continuous variables and descriptive statistics (frequencies and percentages) for categorical variables. The prevalence rates of emotional and behavioural problems were compared according to sociodemographic characteristics using the $\chi^{2}$ test. Binary logistic regression was used to assess the differences in emotional and behavioural problems between Jordanians and Syrians while adjusting for confounding factors. The dependent variable was the participants' ethnicity, defined as o, Jordanian nationality and 1, Syrian nationality. Age, gender, income, parents' education, parents' current marital status, living area, family size, and high risk of emotional and behavioural symptoms defined by abnormal SDQ scales' scores, above the cutoff values, were included as independent explanatory variables. The variables in the model were checked for multicollinearity using variance inflation factor. Adjusted odds ratio (OR) and 95\% confidence intervals (CI) were reported. P $\leq 0.05$ was considered statistically significant. In addition, bivariate correlation using the Pearson correlation coefficient ( $\mathrm{r}$ ) was conducted to assess the relationships between the SDQ scales' scores.

\section{Results}

A total of 3645 participants completed the survey and were included in this study, with an estimated participation rate of $69.1 \%$ (Figure 1). More than half of the participants were female ( $n=2012,55.2 \%$ ), and their mean
(SD) age was 14.7 (1.6) years. There were 1877 Jordanian (45.6\% male and $54.4 \%$ female) and 1768 Syrian refugee (43.9\% male and $56.1 \%$ female) schoolchildren. The ages ranged from 12 to 17 years, with a mean (SD) of 14.8 (1.8) years for Jordanians and 14.5 (1.5) for Syrians. About 7.2\% of Jordanians and $12.8 \%$ of Syrians reported that their parents were separated. Also, more Syrians than Jordanians experienced the death of at least 1 parent (9.0\%) (5.6\%) respectively. Table 2 shows the sociodemographic characteristics of the participants.

The Syrian parents were significantly less educated than the Jordanian parents were. More than half of Syrian children $(70.9 \%)$ reported that 1 or both parents did not attend school or had primary education only. In comparison, among Jordanians, $87.0 \%$ claimed that at least 1 parent had high school or above educational level. Syrian families had significantly lower income [262.1 (179.1) Jordanian dinar (JD)/month] than Jordanian families had [616.3 (587.4) JD/month). The average (SD) number of Syrian family members was 7.1 (2.9), compared with 6.6 (1.9) Jordanian family members. With considering $323 \mathrm{JD} / \mathrm{month}$ as the poverty line in Jordan for an average-sized family of 5.7 members (40), more than two thirds of Syrian families $(76.6 \%)$ were below the poverty line, while only $25.4 \%$ of Jordanians were poor. Thus, Syrian school children came from significantly low-income households, while Jordanian school children were from middle- or high-income households. 


\begin{tabular}{|c|c|c|c|c|c|}
\hline \multirow[t]{2}{*}{ Variable } & \multicolumn{2}{|c|}{ Jordanian adolescents } & \multicolumn{2}{|c|}{ Syrian adolescent refugees } & \multirow[t]{2}{*}{$\mathbf{P}$} \\
\hline & $n$ & $\%$ & $\mathbf{n}$ & $\%$ & \\
\hline Gender & & & & & 0.315 \\
\hline Male & 856 & 45.6 & 777 & 43.9 & \\
\hline Female & 1,021 & 54.4 & 991 & 56.1 & \\
\hline City & & & & & $<0.001$ \\
\hline Mafraq & 483 & 25.7 & 479 & 27.1 & \\
\hline Sahab & 542 & 28.9 & 422 & 23.9 & \\
\hline Zarqa & 616 & 32.8 & 468 & 26.4 & \\
\hline Ramtha & 236 & 12.6 & 399 & 22.6 & \\
\hline Parents' marital status & & & & & $<0.001$ \\
\hline Living together & 1,636 & 87.2 & 1,381 & 78.1 & \\
\hline Separated & 135 & 7.2 & 227 & 12.8 & \\
\hline 1 or both died & 106 & 5.6 & 160 & 9.0 & \\
\hline Mother's education & & & & & $<0.001$ \\
\hline Not educated & 51 & 2.7 & 112 & 6.4 & \\
\hline$<$ than high school & 355 & 19.1 & 937 & 53.5 & \\
\hline High school & 815 & 43.9 & 574 & 32.8 & \\
\hline University & 636 & 34.2 & 128 & $7 \cdot 3$ & \\
\hline Father's education & & & & & $<0.001$ \\
\hline Not educated & 47 & 2.5 & 81 & 4.6 & \\
\hline Below high school & 341 & 18.3 & 885 & 50.2 & \\
\hline High school & 878 & 47.2 & 611 & 34.7 & \\
\hline University & 595 & 32.0 & 186 & 10.6 & \\
\hline $\begin{array}{l}\text { Total family income } \\
\text { (JD)/month) }\end{array}$ & & & & & $<0.001$ \\
\hline$\leq 250$ & 256 & 15.0 & 976 & 63.1 & \\
\hline $251-500$ & 791 & 46.2 & 487 & 31.5 & \\
\hline$>500$ & 665 & 38.8 & 83 & 5.4 & \\
\hline Housing & & & & & $<0.001$ \\
\hline Apartment & 478 & 25.6 & 1,081 & 61.5 & \\
\hline House & 1,390 & 74.4 & 678 & 38.5 & \\
\hline Family size & & & & & $<0.001$ \\
\hline$<6$ & 451 & 24.0 & 428 & 24.2 & \\
\hline 6 & 479 & 25.5 & 374 & 21.1 & \\
\hline 7 & 478 & 25.5 & 346 & 19.6 & \\
\hline$>7$ & 469 & 25.0 & 620 & 35.1 & \\
\hline
\end{tabular}

$J D=$ Jordanian dinar.

The total difficulties score was abnormally high $(\geq 20)$ in $55.2 \%$ of all school children, and more than half of Jordanian and Syrian schoolchildren had peer relationship problems (53.6\% and 55.5\%, respectively). Besides peer relationship problems, Syrian schoolchildren refugees had more conduct problems (47.6\%), emotional symptoms (32.0\%), and total difficulties (58.2\%) compared to Jordanians $(44.8 \%, 30.8 \%$ and $52.5 \%$ respectively). In contrast, Syrian schoolchildren refugees had less hyperactivity/inattention problems $(35.5 \%)$ than their Jordanian peers $(36.9 \%)$, and they had fewer prosocial behaviour problems (42.5\% vs 43.0\%, respectively). Figure 2 shows the percentages of Syrian schoolchildren refugees who scored above the clinical cutoff values of the SDQ scales compared to Jordanians.

Logistic regression analysis indicated that Jordanian and Syrian schoolchildren differed significantly in overall difficulty, emotional symptoms, and peer relationship problems (Table 3). Syrian schoolchildren refugees were more likely to develop overall difficulties and emotional symptoms than Jordanian schoolchildren were. In 
Figure 1 Participants flow chart

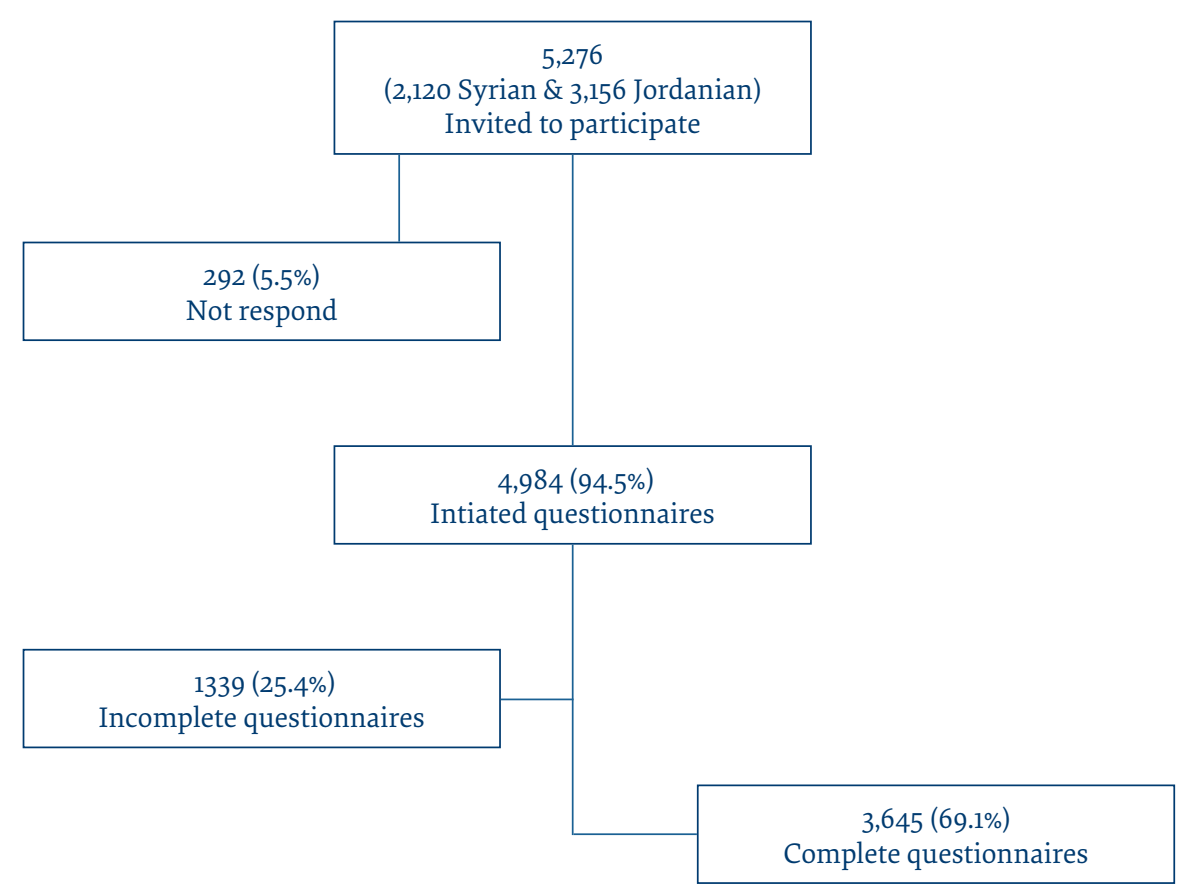

contrast, they were less likely than their Jordanian peers to have peer relationship problems.

The emotional and behavioural problems of the SDQ scales were assessed for gender difference. Girls had a higher risk of developing emotional symptoms (36.4\%) and hyperactivity/inattention problems (40.7\%) than boys were $(25.1 \%, 30.8 \%$ respectively) ( $p<0.001$ for each scale). Conduct problems, $p$-value $=0.003$ were more common among boys than girls ( $48.8 \%$ vs $44.0 \%)$. Also, $(p<0.001$ for each scale) boys had more peer problems (62.9\%) and abnormal prosocial behaviours (52.1\%) compared to girls (47.7\% and $35.1 \%$, respectively).
Regarding the parental social situation, 266 (7.3\%) experienced the death of at least 1 parent, and $362(9.9 \%)$ reported parents' separation, while most children $(n=3017$, $82.8 \%$ ) lived together with their both parents (Table 4). Those who had a history of parental death scored significantly higher on overall difficulties, emotional symptoms, and conduct problems scales compared with children who lived together with their parents or whose parents were separated ( $p<0.005$ for each scale). School children who experienced parental separation had significantly more peer relationship problems (71.5\%) and more prosocial behaviour problems $(54.4 \%)$ than those with parental death (60.2\% and $40.4 \%$, respectively), and

Figure 2 The emotional and behavioural problems among Jordanian schoolchildren and Syrian schoolchildren refugees in Jordan

\section{Overall difficulties}

Prosocial behaviors

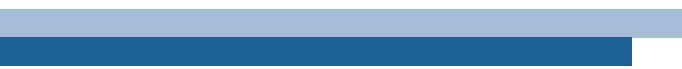

Emotional symptoms

Conduct problems
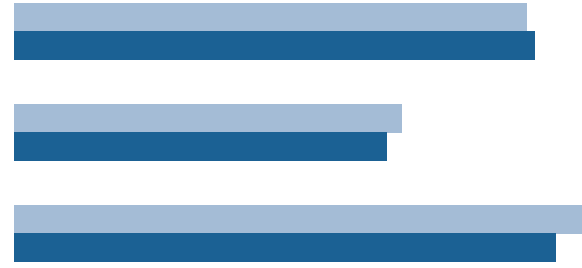

Hyperactivity/Inattention problems

Peer relationship problems

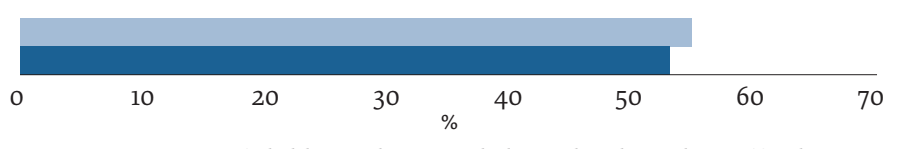

Percentage of children who scored about the clinical cutoff value

Syrian adolescent refugees

Jordanian adolescents 


\begin{tabular}{|c|c|c|c|c|c|}
\hline SDQ scales (abnormal scores) & Beta coefficient & $\begin{array}{l}\text { Adjusted odds } \\
\text { ratio }^{\mathrm{a}}\end{array}$ & \multicolumn{2}{|c|}{$95 \%$ confidence interval } & $\mathbf{P}$ \\
\hline Total difficulties $(20-40)$ & 0.358 & 1.431 & 1.071 & 1.912 & 0.015 \\
\hline Prosocial behaviours (0-4) & 0.009 & 1.009 & 0.818 & 1.244 & 0.933 \\
\hline Emotional symptoms (7-10) & 0.247 & 1.156 & 1.007 & 1.326 & 0.039 \\
\hline Conduct problems (5-10) & -0.104 & 0.901 & 0.713 & 1.140 & 0.386 \\
\hline Hyperactivity/inattention problems (7-10) & -0.128 & 0.880 & 0.706 & 1.096 & 0.254 \\
\hline Peer relationship problems $(6-10)$ & -0.234 & 0.791 & 0.631 & 0.992 & 0.042 \\
\hline
\end{tabular}

${ }^{a}$ Adjusted for age, gender, income, mothers' and fathers' levels of education, parents' current marital status, living area, and family size.

$S D Q=$ Strengths and Difficulties Questionnaire.

who lived with both parents ( $52 \%$ and $41.5 \%$, respectively) ( $p<0.001$ for each scale).

SDQ scale scores showed a negative correlation between prosocial behaviour and emotional symptoms ( $\mathrm{r}$ $=-0.332, P<0.001)$, conduct problems $(r=-0.415, P<0.001)$ and peer relationship problems $(r=-0.239, P=0.001)$. In contrast, emotional symptoms' score was positively correlated with conduct problems $(r=0.545, P<0.001)$, hyperactivity/inattention symtoms $(r=0.457, P<0.001)$, and peer problems $(r=0.370, P<0.001)$. Also, conduct problemsweresignificantlyassociated with hyperactivity/ inattention symptoms $(r=0.420, P<0.001)$ and peer problems $(r=0.218, P<0.001)$. Finally, hyperactivity/ inattention symptoms were positively but weakly correlated with peer relationship problems $(\mathrm{r}=0.057$, $P=0.002)$.

\section{Discussion}

The prevalence rates of behavioural and emotional symptoms for all SDQ domains were common among both Syrian and Jordanian schoolchildren. Syrian schoolchildren refugees had a higher risk of developing total difficulties and emotional symptoms than their Jordanian peers had. Experiencing death or separation of parents, low parental educational levels, low family income, and large family size were prevalent among Syrian refugees, contributing significantly to developing behavioural and emotional problems. Thus, these challenges affect the mental health and psychosocial wellbeing of Syrian refugee children.

The Syrian refugees suffered from conflictrelated violence coupled with the ongoing stressors related to displacement, explaining their emotional and behavioural problems. Our findings highlighted increased emotional and behavioural problems among child survivors of the Syrian Civil War by showing high rates of possible peer relationship, conduct and prosocial problems. In Turkey, another neighbouring country of the Syrian Arab Republic and the largest Syrian refugee-hosting country (16), the prevalence estimates of behavioural and emotional symptoms among Syrian refugee children were higher than those in the general population (41). In another Turkish study, prevalence rates among Syrian refugee children were as high as our findings, with $64.9 \%$ for peer relationship problems, $45.5 \%$ for emotional problems, $39 \%$ for total difficulties, $27.3 \%$ for conduct problems, $19.5 \%$ for hyperactivity problems and 2.6\% for abnormal prosocial behaviours (42). In Iraq, all Yazidi children and adolescents, who were forcibly displaced following war, exhibited several psychiatric symptoms and disorders; 50\% had 1 symptom, and 50\% had more than 1 (43). A study of the epidemiology of PTSD and depression among refugee children resettled in developed countries reported high incidence rates for depression and PTSD (44).

Our study demonstrated high levels of peer relationship and prosocial problems that are not commonly studied among child survivors of war. This indicates that adverse psychological consequences of war-related experiences might not be limited to emotional problems. Similarly, high prevalence rates of conduct problems were noted among Syrian children; not often studied among child survivors of war and violence. These findings

\begin{tabular}{|c|c|c|c|c|}
\hline SDQ scales (abnormal scores) & $\begin{array}{c}\text { Children living together with } \\
\text { both parents } \\
n=3017(\%)\end{array}$ & $\begin{array}{c}\text { Parents' separation } \\
n=362(\%)\end{array}$ & $\begin{array}{l}\text { Parental death } \\
n=266(\%)\end{array}$ & $\mathbf{P}$ \\
\hline Total difficulties $(20-40)$ & $1603(53.2)$ & $229(63.3)$ & $179(67.5)$ & $<0.001$ \\
\hline Prosocial behaviours $(0-4)$ & $1252(41.5)$ & $197(54.4)$ & $107(40.4)$ & $<0.001$ \\
\hline Emotional symptoms (7-10) & $908(30.1)$ & $120(33.1)$ & $114(43.0)$ & $<0.001$ \\
\hline Conduct problems (5-10) & $1360(45.2)$ & $177(48.9)$ & $140(52.8)$ & 0.032 \\
\hline Hyperactivity/inattention problems $(7-10)$ & $1086(36.2)$ & $120(33.1)$ & $108(40.8)$ & 0.147 \\
\hline Peer relationship problems $(6-10)$ & $1563(52.0)$ & $259(71.5)$ & $159(60.2)$ & $<0.001$ \\
\hline
\end{tabular}


shed light on the importance of addressing behavioural symptoms as much as emotional problems.

Unexpectedly, Jordanian schoolchildren studying at the same schools as Syrian schoolchildren refugees were found to have comparatively high levels of behavioural and emotional symptoms. The prevalence rates of emotional and behavioural problems among Jordanian school children were higher than those in other countries, including New Zealand, where prevalence rates ranged from $2 \%$ for peer problems to $11 \%$ for conduct problems (45), Islamic Republic of Iran (6-24\% for all SDQ domains) (46), and other countries in the Middle East (47).

However, our results are concordat with other reports from Jordan (48-50). Behavioural and emotional symptoms among Jordanian schoolchildren could be attributed to the dearth of adolescent and child mental health services in Jordanian schools, as only $12 \%$ of schools offer counselling services (6). Also, mental health illiteracy, shortage of research, and limited advocacy bodies are other reasons for this finding. Jordan suffers from limited natural resources, low- to middle-income rates and economic challenges that have been worsened by the Syrian and Iraqi crises. The large number of Syrian refugees entering the country had a substantial impact on the country's economy and social structure, with many Jordanians facing job shortages and intense competition for scarce resources. Other significant challenges facing Jordan include high unemployment, and continued pressure on the existing national health system and services. Economic challenges, job competition, and limited schools and national resources have created significant concerns for some Jordanian families that could reduce their mental wellbeing and capacity to care for children. Jordanians continue to suffer and share scarce resources with the Syrians, while the Syrians have demonstrated remarkable resiliency after several years of resettlement (5).

Emotional symptoms and hyperactivity/inattention problems were more prevalent among girls than boys, while conduct and peer relationship problems and prosocial behaviour were higher among boys than girls in our study. Our findings are concordant with Çeri et al. who reported more emotional problems among girls and more conduct problems among boys (42). Thus, traumatic events may influence boys and girls in different ways; for example, boys are prone to externalization or behavioural problems, while girls are prone to internalization problems (depression and anxiety disorders) after traumatic events (51). Therefore, precise evaluation of psychiatric disorders should be conducted to explore the effects of displacement and war on mental health regardless of gender.

Our findings demonstrated negative correlations of prosocial behaviours with emotional, conduct and peer relationship problems. Thus, prosocial skills could be a protective factor against developing mental health symptoms and psychosocial problems. In contrast, emotional, conduct, hyperactivity/inattention, and peer relationship problems were positively correlated.
Therefore, they could be risk factors for mental health symptoms and other psychiatric disorders by deteriorating social attendance. These findings were reported by Çeri et al. (42).

In Jordan, the focus on mental health services for citizens and refugees is insufficient; available resources are limited, with only 3 mental health hospitals, a specialized psychiatric hospital for children, and low rates of psychiatric beds for the population (1:10 000) (19, 52 ). Besides, there are only 1 psychiatrist, 2 psychiatric social workers, and 0.04 psychiatric nurses for 100000 inhabitants in Jordan (52). The lack of insurance coverage for Syrian refugees and the Jordanian community with mental illnesses in the private sector and their high cost exacerbates affordability issues. Also, all primary health care facilities in Jordan are physician-based, in which primary health care physicians are allowed to prescribe psychotropic medications but with restrictions.

To date, no fixed budget is dedicated to mental health services. Despite recent efforts to shift attention and resources to community-based services, the majority (estimated $>90 \%$ ) of financial resources for mental health are currently directed towards tertiary hospitals treating mental disorders. This has represented a considerable challenge to expanding community-based services.

A lack of psychiatric facilities, mental health awareness, professional training, and culturally sensitive psychiatry treatment in Jordan, and poor cooperation between centralized treatment services and clinicians, coupled with social barriers, such as stigma and beliefs about mental illnesses, family structures, education, and religion, have been identified as significant challenges to mental health systems in Arab countries including Jordan (53-56). Thus, the Jordan Ministry of Health National Center for Mental Health is invited, as a leader of mental health services in Jordan, to make improvements by incorporating mental health care into primary care; increasing mental healthcare awareness among primary care physicians to improve screening; providing training for specialists in mental health; improving social services in communities; and promoting community psychology programmes. Solid educational campaigns are suggested to occur at all levels to inform the public about mental health issues, with a goal of reducing stigma and encouraging those in need to access available services. Also, prioritizing the developmental needs of children and adolescents (emotional, social, educational, physical and cognitive) in schools is needed, including support to parents desperate to ensure the wellbeing of their children.

This study had a few limitations. The lack of available data on nonrespondents and the cross-sectional design are inherent limitations that could affect interpretation of the results. Although the relatively large sample was collected from different areas, the achieved representativeness was low, limiting our findings to the broader populations of Jordanian and Syrian schoolchildren. Thus, the results are unlikely to be generalized beyond the people who responded. The response rate $(69 \%)$ was good, but 
monetary incentives are suggested to achieve a better response rate, and we suggest inserting an instructional manipulation check such as a blue-dot task to increase the statistical power and reduce the signal-to-noise ratio. Additionally, because this was a survey-based study in the absence of teachers and other school personnel, the results are subject to recall, and we could not check if participants' responses were accurate. The factors associated with the psychological symptoms may not be actual risk factors. Thus, longitudinal studies are more likely to yield conclusive information on the prevalence and associated risk factors than cross-sectional studies are.

\section{Conclusion}

Behavioural and emotional symptoms are common among Syrian schoolchildren refugees and Jordanian children sharing the same schools. Syrian schoolchildren refugees have a higher risk of developing total difficul- ties and emotional symptoms than their Jordanian peers have. This necessitates swift interventions to improve adolescents' wellbeing and their psychosocial needs. Thus, we urgently recommend supporting the children's refugees and their peers of the host country with psychosocial support programmes, community outreach activities, awareness campaigns, and other educational programmes. Experiencing death or separation of parents, low parental educational levels, low family income, and large family size, as well as peer relationship, conduct and hyperactivity problems are risk factors for mental health symptoms. On the other hand, prosocial behaviours can serve as protective factors against mental health symptoms. Thus, targeting vulnerable groups is also crucial for implementing effective interventions. We call for increasing awareness of adolescents and parents towards mental health illnesses and available services. Also, more studies are suggested to explore the causes and associated factors with behavioural and emotional symptoms among Syrian and Jordanian schoolchildren.

\section{Acknowledgement}

We would like to acknowledge the financial and technical support from the Deutsche Gesellschaft für Internationale Zusammenarbeit (GIZ).

Funding: None.

Competing interests: None declared.

\section{Symptômes comportementaux et émotionnels chez les écoliers : comparaison entre les Jordaniens et les réfugiés syriens \\ Résumé}

Contexte : La prévalence des maladies mentales, notamment la dépression, l'anxiété, la dépendance à la nicotine et les troubles du sommeil, est élevée chez les adolescents et les écoliers jordaniens. De nombreux jeunes réfugiés syriens en Jordanie présentent un risque accru de maladies physiques et psychologiques.

Objectifs : Évaluer les symptômes comportementaux et émotionnels chez les écoliers syriens réfugiés en Jordanie et leurs camarades jordaniens.

Méthodes : Une étude transversale descriptive a été menée d'octobre à décembre 2018 dans un groupe d'écoliers syriens et jordaniens, âgés de 12 à 17 ans, qui fréquentaient les mêmes écoles dans quatre villes ayant la plus forte densité de réfugiés syriens. Un questionnaire auto-administré a été utilisé pour recueillir des informations sur les caractéristiques socio-démographiques. Le questionnaire sur les points forts et les difficultés a été utilisé pour évaluer les symptômes comportementaux et émotionnels.

Résultats : La présente étude portait sur 1877 écoliers jordaniens et 1768 écoliers syriens réfugiés. Les parents des enfants syriens étaient nettement moins instruits, avaient des revenus considérablement inférieurs et des familles plus nombreuses que les parents jordaniens. Les difficultés totales et les problèmes de relations entre pairs étaient anormalement élevés chez plus de la moitié des enfants. Par rapport aux Jordaniens, les écoliers syriens avaient davantage de difficultés totales $(58,2 \%$ contre $52,5 \%$ ), de problèmes de relations entre pairs $(55,5 \%$ contre $53,6 \%)$, de problèmes comportementaux (47,6 \% contre 44,8\%) et émotionnels (32,0\% contre 30,8 \%), mais ils avaient moins de problèmes d'hyperactivité/inattention (35,5\% contre 36,9\%) et de problèmes liés aux comportements prosociaux (42,5\% contre 43,0\%). À la régression logistique binaire, les écoliers syriens étaient plus susceptibles que les écoliers jordaniens d'éprouver des difficultés générales et des symptômes émotionnels.

Conclusion : Les écoliers syriens et jordaniens présentaient des symptômes comportementaux et émotionnels importants, mais non exprimés, ainsi que des besoins en matière de santé mentale. Ils avaient tous besoin d'un soutien psychosocial urgent. 


\section{الأعر اض السلو كية والعاطفية بين تلاميذ المدارس: مقارنة بين الأردنيين واللاجئين السوريين \\ عثمان بني يونس ، يوسف خضر، عبد الحميد المستريجي، ساره أبوخضير، مراد داوود}

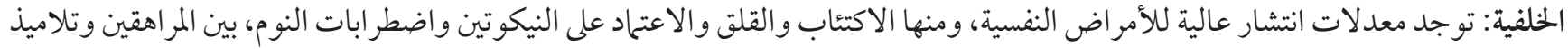
المدارس في الأردن. وفي الأردن كثير من اللاجئين السوريين الشباب الذين النين يزداد خطر إصابتهم بأمر اض بلدنية ونفسية.

الأهداف: هدفت هذه الدراسة إلى تقييم الأعر اض السلوكية والعاطفية بين التلاميذ السوريين اللاجئين في الأردن ونظر ائهم الأردنيين.

طرق البحث: أجريت در اسة وصفية مقطعية في الفترة من أكتوبر / تشرين الأول إلى ديسمبر / كانون الأول

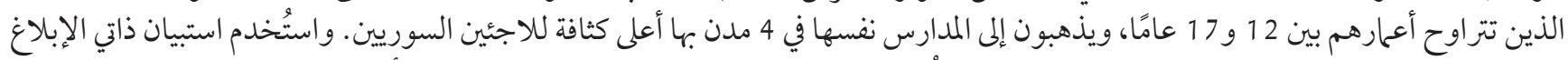

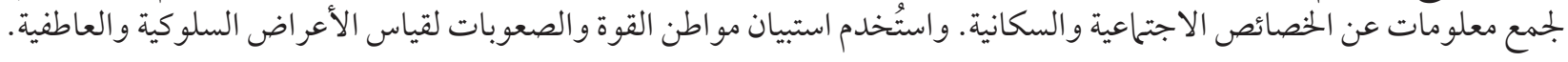

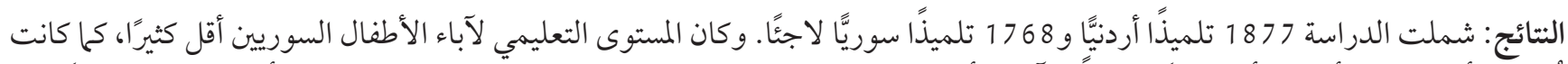

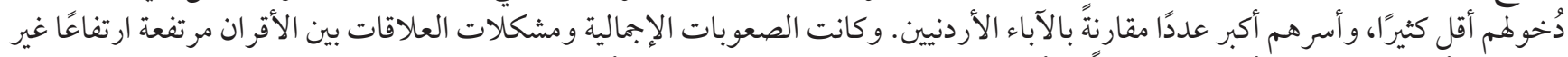

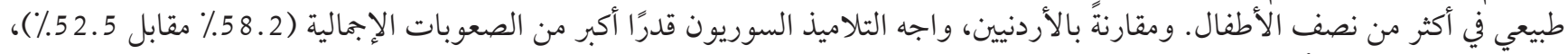

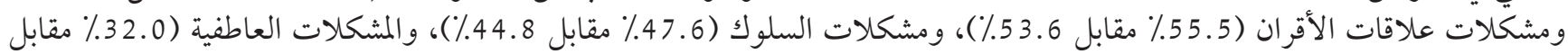

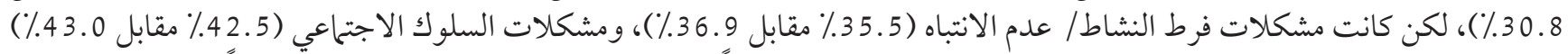

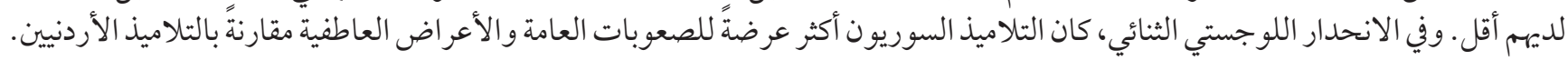
الاستنتاجات: كانت هناك أعر اض سلوكية وعاطفية واحتياجات صحية نفسية كبرى، وإن كانت غير معلنة، بين التلاميذ السوريين والأردنيين.

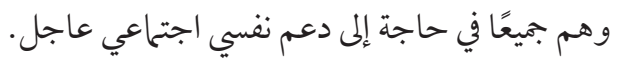

\section{References}

1. The World Health Report 2001: mental disorders affect one in four people. Geneva: World Health Organization; 2001 (https:// www.who.int/news/item/28-09-2001-the-world-health-report-2001-mental-disorders-affect-one-in-four-people, accessed 6 July 2021).

2. Ritchie H, Roser M. Our World in Data. Mental Health. 2021 (https://ourworldindata.org/mental-health, accessed 8 November 2021).

3. Kühn S, Rieger UM. Health is a state of complete physical, mental and social wellbeing and not merely absence of disease or infirmity. Surg Obes Relat Dis. 2017;13:887. https://doi.org/10.1016/j.soard.2017.01.046.

4. Belfer ML. Child and adolescent mental disorders: the magnitude of the problem across the globe. J Child Psychol Psychiatry. 2008 Mar;49(3):226-36. https://doi.org/10.1111/j.1469-7610.2007.01855.x PMID:18221350

5. Patel V, Flisher AJ, Hetrick S, McGorry P. Mental health of young people: a global public-health challenge. Lancet. 2007 Apr 14;369(9569):1302-13. https://doi.org/10.1016/s0140-6736(07)60368-7 PMID:17434406

6. Mental health in Jordan. Cairo: World Health Organization Regional Office for the Eastern Mediterranean; 2021 (http://www. emro.who.int/jor/jordan-news/mental-health-in-jordan.html, accessed 8 November 2021).

7. Ismayilova L, Hmoud O, Alkhasawneh E, Shaw S, El-Bassel N. Depressive symptoms among Jordanian youth: results of a national survey. Community Ment Health J. 2013 Feb;49(1):133-40. https://doi.org/10.1007/s10597-012-9529-7 PMID:22820930

8. Dardas LA, Silva SG, Smoski MJ, Noonan D, Simmons LA. The prevalence of depressive symptoms among Arab adolescents: findings from Jordan. Public Health Nurs. 2018 Mar;35(2):100-8. https://doi.org/10.1111/phn.12363 PMID:29315784

9. Alfoukha MM, Hamdan-Mansour AM, Banihani MA. Social and psychological factors related to risk of eating disorders among high school girls. J Sch Nurs. 2017 Jun;35(3):169-77. https://doi.org/10.1177/1059840517737140 PMID:29073811

10. Abbadi A, Alnahar J, Zoghoul S, Bsoul A, Alarood S, Al-Mistarehi AH et al. Waterpipe Nicotine Dependence and Depressive Symptoms among Adolescent Waterpipe and Dual Users. J Environ Public Health. 2020;2020:Article ID 2364571. https://doi. org/10.1155/2020/2364571.

11. Yassin A, Al-Mistarehi AH, Beni Yonis O, Aleshawi AJ, Momany SM, Khassawneh BY. Prevalence of sleep disorders among medical students and their association with poor academic performance: a cross-sectional study. Ann Med Surg (Lond). 2020 Oct;58:124-9. https://doi.org/10.1016/j.amsu.2020.08.046.

12. Al-Mistarehi A-H, Yassin A, Dulaimy Ö, Banyata R, Masalmeh A, Arar T et al. Water-pipe usage among Jordanian high school students: prevalence and basic features. Eur Resp J.2019;54:PA4466. https://doi.org/10.1183/13993003.congress-2019.PA4466

13. Al-mistarehi A-HWM, Ibnian AM, Shaqadan S, Khassawneh BY. The impact of sleep disorders on academic performance among medical students. Am J Resp Crit Care Med. 2019;199:A4296-A. https://www.atsjournals.org/doi/abs/10.1164/ajrccm-conference.2019.199.1_MeetingAbstracts.A4296 
14. Kheirallah K, Bloukh S, Khasawneh W, Alsulaiman J, Khassawneh A, Al-Mistarehi AH et al. Medical students' relative immunity, or lack thereof, against COVID-19 emotional distress and psychological challenges; a descriptive study from Jordan. F10ooRes. 2021;10:297. https://doi.org/10.12688/f100oresearch.52051.2. PMID:34026047

15. Syria conflict at 5 years: the biggest refugee and displacement crisis of our time demands a huge surge in solidarity. United Nations High Commissioner for Refugees; 2016 (http://www.unhcr.org/56e6e3249.html, accessed 8 November 2021).

16. Syria regional refugee response, inter agency information sharing portal. United Nations High Commissioner for Refugees; 2021 (https://data2.unhcr.org/en/situations/syria, accessed 8 November 2021).

17. Sirin SR, Rogers-Sirin L. The educational and mental health needs of Syrian refugee children. Migration Policy Institute; 2015 (http://old.worldomep.org/wp-content/uploads/2016/02/FCD-Sirin-Rogers-FINAL-4.pdf, accessed 26 April 2019).

18. Al-Momani A. Estimated population of 2020 and some of selected data. Jordan: Jordanian Department of Statistics; 2020 (http:// dosweb.dos.gov.jo/DataBank/Population_Estimares/PopulationEstimates.pdf, accessed 8 November 2021).

19. Understanding the mental health and psychosocial needs, and service utilization of Syrian Refugees and Jordanian nationals: a qualitative \& quantitative analysis in the Kingdom of Jordan. Jordan: International Medical Corps; 2017 (https://reliefweb.int/ report/jordan/understanding-mental-health-and-psychosocial-needs-and-service-utilization-syrian, accessed 8 November 2021).

20. The fiscal impact of the Syrian refugee crisis on Jordan 2014. The United States Agency for International Development; 2014 (https://jordankmportal.com/resources/the-fiscal-impact-of-the-syrian-refugee-crisis-on-jordan-2014, accessed 8 November 2021).

21. Sharp JM. Jordan: background and U.S. relations. Washington, DC: Congressional Research Service; 2016 (https://www.refworld. org/pdfid/56bc46be4.pdf, accessed 8 November 2021).

22. Bean TM, Eurelings-Bontekoe E, Spinhoven P. Course and predictors of mental health of unaccompanied refugee minors in the Netherlands: one year follow-up. Soc Sci Med. 2007 Mar;64(6):1204-15. https://doi.org/10.1016/j.socscimed.2006.11.010 PMID: 17188787

23. Jabbar SA, Zaza HI. Impact of conflict in Syria on Syrian children at the Zaatari refugee camp in Jordan. Early Child Development and Care. 2014;184(9-10):1507-30. https://doi.org/10.1080/03004430.2014.916074.

24. Beni Yonis O, Khader Y, Jarboua A, Al-Bsoul MM, Al-Akour N, Alfaqih MA et al. Post-traumatic stress disorder among Syrian adolescent refugees in Jordan. J Public Health (Oxf). 2020 May 26;42(2):319-24. https://doi.org/10.1093/pubmed/fdz026 PMID:30927431

25. Affouneh SJ. How sustained conflict makes moral education impossible: some observations from Palestine. J Moral Educ. 2007;36(3):343-56. https://doi.org/10.1080/03057240701553321.

26. Reed RV, Fazel M, Jones L, Panter-Brick C, Stein A. Mental health of displaced and refugee children resettled in low-income and middle-income countries: risk and protective factors. Lancet. 2012 Jan 21;379(9812):250-65. https://doi.org/10.1016/so1406736(11)60050-0 PMID: 2183546

27. Fazel M, Reed RV, Panter-Brick C, Stein A. Mental health of displaced and refugee children resettled in high-income countries: risk and protective factors. Lancet. 2012 Jan 21;379(9812):266-82. https://doi.org/10.1016/so140-6736(11)60051-2 PMID:21835459

28. Rousseau C. The Mental Health of Refugee Children. Transcultural Psychiatric Research Review. 1995;32(3):299-331. https://doi. org/10.1177/136346159503200304.

29. Ortuño-Sierra J, Fonseca-Pedrero E, Inchausti F, Riba SSi. Assessing behavioral and emotional difficulties in the child-adolescent population: the Strengths and Difficulties Questionnaire (SDQ). Papeles del Psicólogo. 2016;37(1):14-26. http://www.papelesdelpsicologo.es/English/2658.pdf

30. Mental health psychosocial and child protection for Syrian adolescent refugees in Jordan. June 2014 report. IMC, UNICEF; 2014 (https://reliefweb.int/sites/reliefweb.int/files/resources/finalIMCUNICEFupdatingassessment.pdf, accessed 8 November 2021).

31. Mental health psychosocial and child protection for Syrian adolescent refugees in Jordan. December 2014 report. IMC, UNICEF; 2014 (https://www.alnap.org/system/files/content/resource/files/main/30-finalimcunicefupdatedassessmentlongvers2014-12. pdf, accessed 8 November 2021).

32. Giannakopoulos G, Tzavara C, Dimitrakaki C, Kolaitis G, Rotsika V, Tountas Y. The factor structure of the Strengths and Difficulties Questionnaire (SDQ) in Greek adolescents. Ann Gen Psychiatry. 2009 Aug 26;8:20. https://doi.org/10.1186/1744-859x-8-20 PMID:19709422

33. Goodman R. Psychometric properties of the strengths and difficulties questionnaire. J Am Acad Child Adolesc Psychiatry. 2001 Nov;40(11):1337-45. https://doi.org/10.1097/00004583-200111000-00015.

34. Stolk Y, Kaplan I, Szwarc J. Review of the strengths and difficulties questionnaire translated into languages spoken by children and adolescents of refugee background. Int J Methods Psychiatr Res. 2017 Dec;26(4):e1568. https://doi.org/10.1002/mpr.1568 PMID:28449279

35. Essau CA, Olaya B, Anastassiou-Hadjicharalambous X, Pauli G, Gilvarry C, Bray D et al. Psychometric properties of the Strength and Difficulties Questionnaire from five European countries. Int J Methods Psychiatr Res. 2012 Sep;21(3):232-45. https://doi. org/10.1002/mpr.1364 PMID:22890628

36. Almaqrami MH, Shuwail AY. Validity of the self-report version of the strengths and difficulties questionnaire in Yemen. Saudi Med J. 2004 May;25(5):592-601. PMID:15138526 
37. Goodman R, Meltzer H, Bailey V. The Strengths and Difficulties Questionnaire: a pilot study on the validity of the self-report version. Int Rev Psychiatry. 2003 Feb-May;15(1-2):173-7. https://doi.org/10.1080/0954026021000046137 PMID:12745329

38. Goodman R, Meltzer H, Bailey V. The Strengths and Difficulties Questionnaire: a pilot study on the validity of the self-report version. Eur Child Adolesc Psychiatry. 1998 Sep;7(3):125-30. https://doi.org/10.1007/s007870050057 PMID:9826298

39. Alyahri A, Goodman R. Validation of the Arabic Strengths and Difficulties Questionnaire and the Development and Well-Being Assessment. East Mediterr Health J. 2006;12 Suppl 2:S138-46. PMID:17361685

40. Lenner K. Poverty and poverty reduction policies in Jordan. Presses de l'Ifpo; 2013 (https://books.openedition.org/ifpo/5036?lang=en\#authors, accessed 8 November 2021).

41. Gormez V, Kılıç HN, Orengul AC, Demir MN, Demirlikan Ş, Demirbaş S et al. Psychopathology and associated risk factors among forcibly displaced Syrian children and adolescents. J Immigr Minor Health. 2018 Jun;20(3):529-35. https://doi.org/10.1007/ S10903-017-0680-7 PMID:29204726

42. Veysi Ç, Serhat N. The number of war-related traumatic events is associated with increased behavioural but not emotional problems among Syrian refugee children years after resettlement. 2018;45:100-5. doi: https://doi.org/10.1590/0101-60830000000167.

43. Ceri V, Özlü-Erkilic Z, Özer Ü, Yalcin M, Popow C, Akkaya-Kalayci T. Psychiatric symptoms and disorders among Yazidi children and adolescents immediately after forced migration following ISIS attacks. Neuropsychiatr. 2016;30(3):145-50. https://doi. org/10.1007/s40211-016-0195-9 PMID:27628299

44. Reavell J, Fazil Q. The epidemiology of PTSD and depression in refugee minors who have resettled in developed countries. J Ment Health. 2017 Feb;26(1):74-83. https://doi.org/10.1080/09638237.2016.1222065 PMID:27684305

45. Black S, Pulford J, Christie G, Wheeler A. Differences in New Zealand secondary school students' reported strengths and difficulties. N Z J Psychol. 2010;39:19-23.

46. Mohammadi MR, Arman S, Khoshhal Dastjerdi J, Salmanian M, Ahmadi N, Ghanizadeh A et al. Psychological problems in Iranian adolescents: application of the self report form of strengths and difficulties questionnaire. Iran J Psychiatry. 2013 Oct;8(4):152-9. PMID:25628707

47. Salmanian M, Asadian-Koohestani F, Mohammadi MR. A systematic review on the prevalence of conduct disorder in the Middle East. Soc Psychiatry Psychiatr Epidemiol. 2017 Nov;52(11):1337-43. https://doi.org/10.1007/soo127-017-1414-9 PMID:28681265

48. Shaheen A, Nassar O, Saleh M, Arabia T D. Understanding of school related factors associated with emotional health and bullying behavior among Jordanian adolescents. Iran J Public hHealth. 2014 Nov;43(11):1528-36. PMID:26060720

49. The Middle East and North Africa Out-of-School Children Initiative. Jordan Country Report on out-of-school children. UNICEF: 2020 (https://www.unicef.org/jordan/media/5501/file/OSC-Report-EN.pdf, accessed 8 November 2021).

50. Raffee LA, Al-Qudah MA, Hayajneh WA, Alawneh KZ, Mahasneh OI, Alomari MM et al. Prevalence estimates of drug addiction among high-school students and its association with violence, and school behaviors: a cross-sectional study from Jordan. Ann Med Surg. 2021 Jul;67:102490. https://doi.org/10.1016/j.amsu.2021.102490.

51. Kolltveit S, Lange N, II, Thabet AA, Dyregrov A, Pallesen S, Johnsen TB et al. Risk factors for PTSD, anxiety, and depression among adolescents in Gaza. J Trauma Stress. 2012 Apr;25(2):164-70. https://doi.org/10.1002/jts.21680 PMID:22522730

52. Nolan K. Jordan's mental healthcare system. Independent Study Project (ISP) Collection; 2011 (https://digitalcollections.sit.edu/ isp_collection/1015, accessed 8 November 2021).

53. Nasir LS, Al-Qutob R. Barriers to the diagnosis and treatment of depression in Jordan. A nationwide qualitative study. J Am Board Fam Pract. 2005 Mar-Apr;18(2):125-31. https://doi.org/10.3122/jabfm.18.2.125 PMID:15798141

54. Okasha A, Karam E, Okasha T. Mental health services in the Arab world. World Psychiatry. 2012 Feb;11(1):52-4. https://doi. org/10.1016/j.wpsyc.2012.01.008 PMID:22295010

55. Dalky HF. Perception and coping with stigma of mental illness: Arab families' perspectives. Issues Ment Health Nurs. 2012 Jul;33(7):486-91. https://doi.org/10.3109/01612840.2012.676720 PMID:22757601

56. Corrigan P. How stigma interferes with mental health care. Am Psychol. 2004 Oct;59(7):614-25. https://doi.org/10.1037/0003066x.59.7.614 PMID:15491256 